\title{
Genome-Wide Transcript Expression Analysis in the Uterovaginal Junction in Association with Fertile Period in Tsaiya Ducks
}

\author{
Hsiu-Lin HUANG ${ }^{1-3)}$, Yu-Shin CHENG ${ }^{4)}$, Kuo-Tai YANG ${ }^{5)}$, Chia-Hsuan CHEN"), \\ Mu-Chiou HUANG ${ }^{2}$ and Wen-Hwei HSU ${ }^{3)}$ \\ 1) Department of Biotechnology, MingDao University, ChangHua 523, Taiwan \\ 2) Department of Animal Science, National Chung Hsing University, Taichung 402, Taiwan \\ 3) Institute of Molecular Biology, National Chung Hsing University, Taichung 402, Taiwan \\ 4) Livestock Research Institute, Council of Agriculture, Tainan 712, Taiwan \\ 5) Institute of Biomedical Sciences, Academia Sinica, Taipei 115, Taiwan
}

\begin{abstract}
We performed the first genome-wide expression analysis to compare the differences in gene expression in the female sperm reservoir of the duck reproductive tract between two groups with long and short fertile periods to identify factors that may be associated with the fertile period using an oligonucleotide microarray. RNA was extracted from the uterovaginal junction (UV junction) of the two groups. Affymetrix chips containing comprehensive coverage of 32773 transcripts were hybridized with biotin-labeled cRNA, and three biological repeats were performed. We identified 27 transcripts as being differentially regulated. Interestingly, by mapping the differentially expressed transcripts to annotated pathways, we found that Neuropeptide Y (NPY), the RNA expression of which was increased by 2.96-fold in the short-fertile-period group as compared with the long-fertile-period group in our experiment, has been shown to reduce blood flow and substance supply to local tissues. Enah/Vasp-like (EVL), the RNA expression of which was significantly increased by 1.77-fold in the short-fertile-period group as compared with the long-period group, has been demonstrated to be important in activated T-cells. In contrast, trafficking kinesin-binding protein 1 (TRAK1), the expression of which was increased by 2.33-fold in the long-period group as compared with its counterparts, has been suggested to inhibit precocious activation of sperm and prolong sperm life in the female sperm reservoir. The results of real-time PCR confirmed the data obtained by microarray analysis. Our study demonstrated that combining global gene expression investigation with annotated pathway resources contributes to the understanding of sperm life when sustained in the UV junction.

Key words: Differentially expressed transcripts, Duck, Fertile period, Uterovaginal junction
\end{abstract}

(J. Reprod. Dev. 57: 731-736, 2011)

A fter the entry of sperm into a female genital tract before ovulation, sperm accumulate to a certain amount and are stored in the female sperm reservoir [1], which is a widespread phenomenon among numerous avian, reptilian and mammalian species [2-4]. The sperm reservoir then releases sperm gradually for successful fertilization after a single insemination, the period of which varies from hours to weeks in different species [2, 4-6]. This period is defined as the fertile period. A long fertile period means prolonged sperm survival and leads to a high fertilization rate [7].

The process of sperm migration in the female genital tract is more than simply transportation from the position of insemination to the position of fertilization. Rather, it is a complex continuum: entry into the lower genital tract, defense against the tract environment and immunological response, retention in the storage reservoir, activation, taxiing of activated sperm towards oocytes [8], and phagocytosis of nonfertilizing sperm. During sperm storage in the reservoir of the female reproductive tract, there is a close interac-

Received: April 4, 2011

Accepted: August 8, 2011

Published online in J-STAGE: September 6, 2011

(C)2011 by The Society for Reproduction and Development.

Correspondence: M-C Huang (e-mail: mchuang@mail.nchu.edu.tw) and W-H Hsu (e-mail: whhsu@dragon.nchu.edu.tw) tion between sperm and the epithelium, which can be visualized in a scanning electron micrograph [9]. This close contact has been shown to maintain sperm viability [10-12] and to prevent sperm precocious activation [13].

The location of the sperm storage reservoir varies in different species. In poultry, the uterovaginal sperm storage tubule (UV$\mathrm{SST})[14,15]$ functions as a sperm reservoir, and the uterotubal junction-isthmus stores sperm in cattle and pigs [16-18]. A visibly distinct sperm reservoir has not been found in humans, but a functional reservoir is suggested to exist in the female genital tract, as pregnancy has been shown to result from coitus as long as five days in the past [6]. Although carbohydrate moieties on the epithelium in the female genital tract have been demonstrated to interact with sperm by an experiment concerning competitive inhibition by different carbohydrates in vitro [17, 19], little is known about the molecules participating in sperm life when sustained in the sperm reservoir of the female genital tract.

Due to the fact that ducks and chickens belong to the same class, Aves, highly conserved DNA sequences, which are applicable for different analyses, are shared between them [20]. The Tsaiya duck is the major egg-laying duck in Taiwan [21, 22]. In this study, targets were prepared from long- and short-fertile-period groups of ducks and hybridized with commercially available chicken oligo- 
(a)

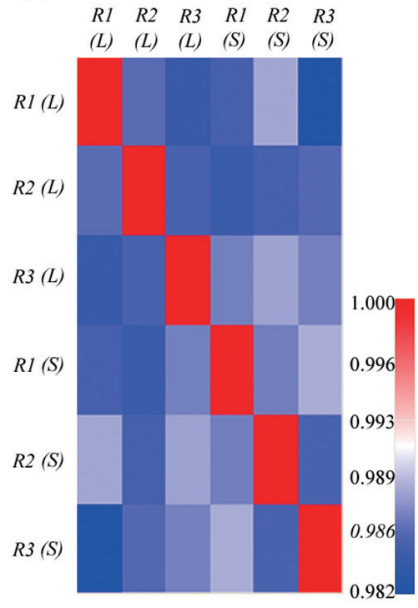

(b)

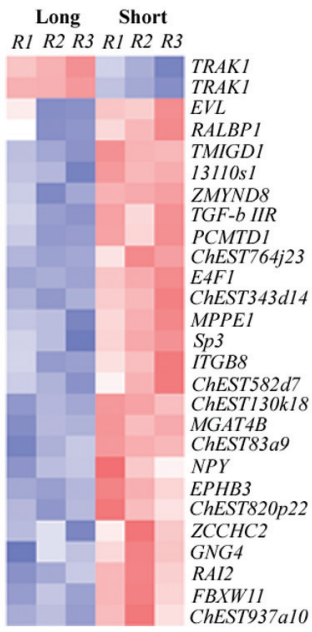

Fig. 1. (a) Quality control for the three independent biological repeats in the oligonucleotide arrays. Pearson correlations indicated that the biological repeats were highly correlated with each other and could be analyzed together. R, repeat; L, long-fertile-period; S, short-fertile-period. (b) Cluster analysis. Twenty-seven transcripts were identified as being correlated with the fertile period. The array signal values for these transcripts were used to drive cluster analysis. The meanings of the red and blue colors in (a) and (b) differ; this is explained in the text.

nucleotide chips. We present new data on gene expression in the two groups with extreme fertile periods and discuss the possible implications in terms of sperm life extension in the reservoir of the female reproductive tract.

\section{Materials and Methods}

\section{Animals and isolation of RNA from UV junction}

Records of the related reproductive performance of the ducks were kept after their sexual maturation, and the animals were sacrificed for sample collection at 42 weeks, which is still within the high-laying-performance phase. The epithelium cells in the UV junctions were collected, as described previously [12], from 12 laying brown Tsaiya ducks with either a long fertile period (12.17 \pm 0.70 days, $n=6)$ or a short fertile period $(5.58 \pm 0.80$ days, $n=6)$. The total RNA was isolated from epithelium cells using RareRNA reagent (GenePure, Kaysville, UT, USA) in accordance with the manufacturer's instructions; equal amounts of RNA samples extracted from every two ducks in each group were pooled together as an independent RNA pool resulting in a total of six independent RNA pools used for microarray hybridization or real-time PCR. All samples were collected from birds reared in the breeding stock of the Taiwan Livestock Research Institute, Council of Agriculture. The care and use of research animals were within standard ethical guidelines, and the protocols were approved by the Livestock Research Institute, Council of Agriculture and National Chung Hsing University.

\section{Target preparation and microarray hybridization}

Target preparation for microarray hybridization was performed according to the manufacturer's instructions (http://media.affymetrix.com/support/downloads/manuals/3 ivt_express_kit_manual. pdf). Briefly, the total RNA sample was reverse transcribed to firststrand cDNA and then converted into a double-stranded DNA template for further in vitro transcription. The procedure was followed by cRNA amplification for $16 \mathrm{~h}$ with biotin labeling, and the biotinlabeled cRNA sample was subsequently purified and fragmented to 35 to $200 \mathrm{nt}$ cRNA. Ten micrograms of biotin-labeled fragments were then hybridized onto an Affymetrix GeneChip ${ }^{\circledR}$ Chicken Genome Array, and the expression levels of 32773 chicken transcripts were monitored on each of six chips, i.e., three biological repeat pairs (each pair containing the long- and short-fertile-period group samples) were performed with six independent RNA pools. Finally, GeneChips were washed and stained with streptavidin-phycoerythrin using an Affymetrix Fluidics Station 450.

\section{Microarray analysis}

The Affymetrix GeneChip ${ }^{\circledR}$ Chicken Genome Arrays were scanned using a GeneChip ${ }^{\circledR}$ Scanner $30007 \mathrm{G}$ (Affymetrix), and raw CEL files were obtained from the GeneChip ${ }^{\circledR}$ Operating Software (GCOS, Affymetrix). The raw data were then processed and normalized by dChip Analyzer [23]. To summarize the analysis procedure, the intensities of the arrays were adjusted according to a baseline array, which had a median overall brightness at the probe intensity level by the Invariant Set Normalization method. A model-based (PM/MM difference) method was used to obtain background-subtracted signal values from each array. Significantly differentially expressed transcripts were filtered to meet three criteria: a fold change of at least 1.2-fold between the long- and shortfertile-period groups; and a difference of at least 100 Affymetrix arbitrary units between the two extreme groups; a P-value of < 0.05 by the $t$-test. Pearson correlations were plotted (Fig. 1a) by the Expression Console analysis package (Affymatrix), and the cluster analysis graph was plotted by dChip Analyzer (Fig. 1b). We mapped differentially expressed transcripts to biological pathways as defined by databases such as the GenMAPP [24] pathway database using the Advanced Pathway Painter software (www.gsaonline.de/eng/app.html).

\section{Examination of differentially expressed transcripts}

Ten nanograms of total RNA were reverse transcribed to cDNA using a High-Capacity cDNA Reverse Transcription Kit (Applied Biosystems) as recommended by the manufacturer. The resulting cDNA was subjected to real-time quantitative PCR with SYBR Green Mix (Applied Biosystems) along with an NPY (UniGene, Gga837)-specific primer set (forward, 5'-TTC GAT GTG GTG ATG GGA TTT-3'; reverse, 5'-TCA GTA CAA TGG CTG CAT GCA-3'), an EVL (UniGene, Gga15399)-specific primer set (forward, 5'-TTA GCA GAC TCA GCA CAC TTT GAA-3'; reverse, 5'TCC AAT GTG CAG TGT CAG ATG A-3') or a TRAK1 (UniGene, Gga26340)-specific primer set (forward, 5'-GAA TAA CCC CCG CCA ATC TC-3'; reverse, 5'-CCT CAC CAG ACC CCT CAT CAT$3^{\prime}$ ) using an Applied Biosystems 7300 (Applied Biosystems) in accordance with the manufacturer's instructions. The cDNA en- 
Table 1. Two transcripts upregulated in the long-fertile-period group and 25 transcripts upregulated in the short-fertile-period group

\begin{tabular}{|c|c|c|c|}
\hline Gene & Gene symbol & $\begin{array}{l}\text { Fold } \\
\text { change }\end{array}$ & $\begin{array}{l}\text { Paired } \\
\text { P value }\end{array}$ \\
\hline Neuropeptide Y & NPY & -2.96 & 0.05 \\
\hline EPH receptor B3 & EPHB3 & -2.39 & 0.02 \\
\hline Gallus gallus finished cDNA, clone ChEST764j23 & ChEST764j23 & -2.34 & 0.04 \\
\hline Similar to TGF-beta type II receptor & Similar to $T G F-\beta I I R$ & -2.25 & 0.02 \\
\hline Gallus gallus finished cDNA, clone ChEST820p22 & ChEST820p22 & -2.25 & 0.05 \\
\hline Transmembrane and immunoglobulin domain containing 1 & $T M I G D 1$ & -2.23 & 0.04 \\
\hline Guanine nucleotide binding protein (G protein), gamma 4 & GNG4 & -2.12 & 0.05 \\
\hline Mannosyl (alpha-1,3-)-glycoprotein beta-1,4-N-acetylglucosaminyltransferase, isozyme B & $M G A T 4 B$ & -1.91 & 0.02 \\
\hline Gallus gallus finished cDNA, clone ChEST83a9 & ChEST83a9 & -1.84 & 0.01 \\
\hline Integrin, beta 8 & ITGB8 & -1.82 & 0.02 \\
\hline Gallus gallus finished cDNA, clone ChEST582d7 & ChEST582d7 & -1.78 & 0.02 \\
\hline Enah/Vasp-like & $E V L$ & -1.77 & 0.02 \\
\hline RalA binding protein 1 & $R A L B P 1$ & -1.64 & 0.03 \\
\hline Zinc finger, $\mathrm{CCHC}$ domain containing 2 & $\mathrm{ZCCHC2}$ & -1.62 & 0.03 \\
\hline Metallophosphoesterase 1 & MPPE1 & -1.59 & 0.01 \\
\hline E4F transcription factor 1 & $E 4 F 1$ & -1.57 & 0.02 \\
\hline Protein-L-isoaspartate (D-aspartate) O-methyltransferase domain containing 1 & PCMTD1 & -1.55 & 0.01 \\
\hline Retinoic acid induced 2 & $R A I 2$ & -1.52 & 0.05 \\
\hline $\mathrm{Sp} 3$ transcription factor & $S P 3$ & -1.49 & 0.01 \\
\hline F-box and WD repeat domain containing 11 & $F B X W 11$ & -1.49 & 0.03 \\
\hline Gallus gallus finished cDNA, clone ChEST937a10 & ChEST937a10 & -1.48 & 0.04 \\
\hline Gallus gallus cDNA clone 13110s1 & $13 l 10 s 1$ & -1.47 & 0.04 \\
\hline Zinc finger, MYND-type containing 8 & ZMYND8 & -1.34 & 0.02 \\
\hline Gallus gallus finished cDNA, clone ChEST130k18 & ChEST130k18 & -1.33 & 0.01 \\
\hline Gallus gallus finished cDNA, clone ChEST343d14 & ChEST343d14 & -1.33 & 0.03 \\
\hline Trafficking protein, kinesin binding 1 & $T R A K 1$ & 2.22 & 0.01 \\
\hline Trafficking protein, kinesin binding 1 & TRAK1 & 2.33 & 0.01 \\
\hline
\end{tabular}

coding $18 s$ rRNA was amplified for normalization (using the following primer set: forward, 5'-GGA CGC GTG CAT TTA TCA GA-3'; reverse, 5'- AGT TGA TAG GGC AGA CAT TCG AA-3'), and relative quantification was performed from curves generated for individual genes and 18s rRNA. Details of the method used are available at http://www3.appliedbiosystems.com/cms/groups/ mcb_support/documents/generaldocuments/cms_053412.pdf.

\section{Results}

\section{High degree of array signal Pearson correlation}

In the calculation of Pearson's correlation for the quality control of arrays (Fig. 1), a very high degree of array signal Pearson correlation $(r>0.982)$ was observed for all pairwise comparisons, demonstrating that the signal variations of the three repeat pairs, a total of six experiments, were very small and that all the six chips can therefore be used for analysis to identify differences in transcript expression. The precision and consistency of the incubation times for our in vitro transcription and of all operations performed during these experiments determined the reliability of the results obtained from the six microarrays. In Fig. 1(a), red and blue represent correlations from higher to lower ( $\gamma$ value of 1.00 to 0.982 ); the closer the $\gamma$ value is to 1.00 , the redder the color, and vice versa.
Reproducibility of the independent biological repeats

The results of microarray analysis showed 27 significantly differentially expressed transcripts when a fold change $>1.2$ and $<-1.2$, a difference of $>100$ Affymetrix arbitrary units between the two groups and a $\mathrm{p}$-value $<0.05$ were used as the cut-off values, two of which were upregulated and 25 of which were downregulated (Table 1). The hierarchical plot shown lists all transcripts with significant differences in expression (Fig. 1(b)), and the gene code section is listed at the right of the graph. These results were based on the data obtained from the two groups with long and short fertile periods (labeled at the top of the graph). Increased expression of the transcripts in a group compared with the other group is indicated in red; decreased transcript expression in a group compared with the other group is indicated in blue. The deeper the red or blue color, the greater the percentage of increase or decrease, respectively. Overall, the results of three independent biological repeats in each group were reproducible; that is, the experiments in triplicate in the longfertile-period group were either all different shades of red (meaning that $T R A K 1$ expression was upregulated in repeats one to three) or different shades of blue (i.e., except for TRAK1, the expressions of the other transcripts in repeats one to three were all decreased, although $E V L$ was shown to be slightly upregulated (very light pink) in repeat one of the long-period group). The results for the replicates in the short-fertile-period group were also reproducible. 
(a)

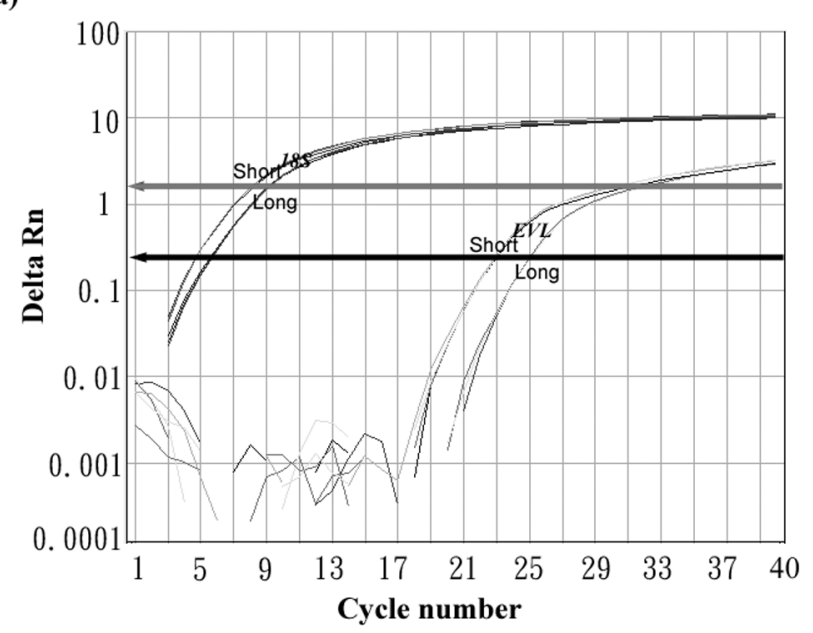

(b)

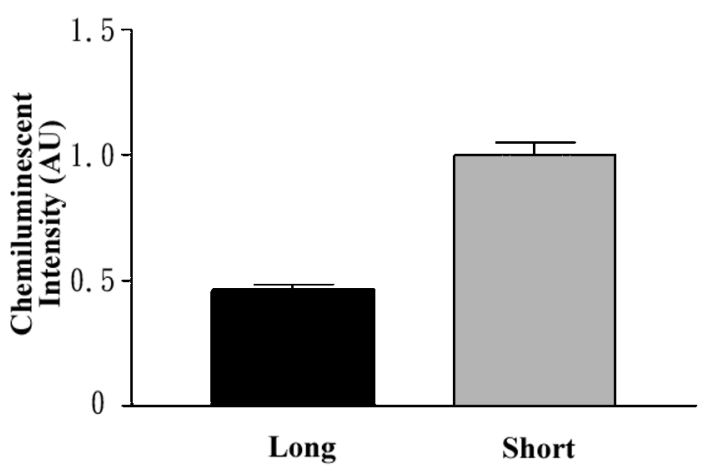

Fig. 2. Differentially expressed $E V L$ gene validation by real-time PCR. (a) Higher amounts of $E V L$ mRNA were expressed in the shortfertile-period group. (b) The quantitative results of $E V L$ expression from (a). Similar results to those observed by microarray demonstrated that the $E V L$ mRNA level was significantly higher in the short-fertile-period group than in the long-fertile-period group. $(\longleftarrow$ and $\longleftarrow$ indicate the analysis thresholds for $E V L$ and $18 S$, respectively.)

\section{Integration of expression data and the annotated pathways}

To identify the possible functions of the 27 transcripts significantly differentially expressed between the long- and short-fertile-period groups, we mapped different transcripts to biological pathways as defined by databases such as the GenMAPP pathway database. The results helped us to choose a subset of interesting genes for further analysis. With regards to the analysis of the oligonucleotide microarrays, the RNA expression of Enah/Vasp-like $(E V L)$ was significantly increased by 1.77 -fold in the short-fertileperiod group as compared with the long-fertile-period group (Table 1). The expression of Neuropeptide $Y(N P Y)$ was also significantly increased by 2.96 -fold in the short-fertile-period group, while the expression of trafficking kinesin-binding protein 1 (TRAKI) was significantly increased by 2.33 -fold in the long-fertile-period group as compared with the short-period group. (a)

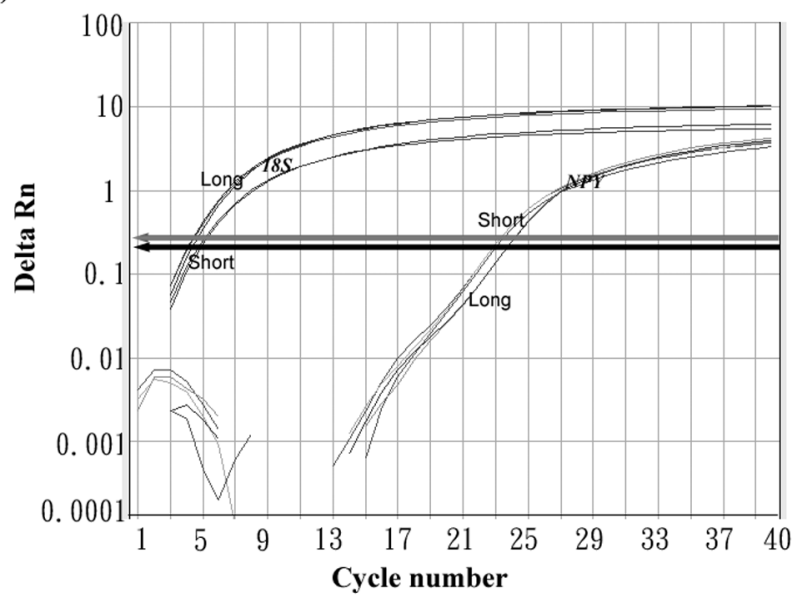

(b)

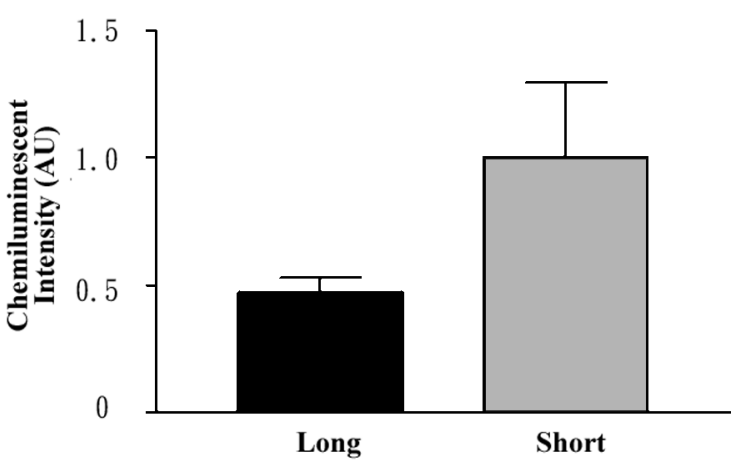

Fig. 3. Differentially expressed $N P Y$ gene validation by real-time PCR. (a) Higher amounts of $N P Y$ mRNA were expressed in the shortfertile-period group. (b) The quantitative results of $N P Y$ expression from (a). Similar results to those observed by microarray demonstrated that the $N P Y$ mRNA level was significantly higher in the short-fertile-period group than in the long-fertile-period group. ( $\longleftarrow$ and $\longleftarrow$ indicate the analysis thresholds for $N P Y$ and $18 S$, respectively.)

Further assessment of EVL, NPY and TRAK1 RNA expression

Real-time PCR investigation confirmed the results obtained by microarray analysis: the EVL RNA expression level $(1.00 \pm 0.05$, Fig. 2) of the short-fertile-period group was significantly higher than that of the long-fertile-period group $(0.46 \pm 0.03$; $\mathrm{P}<0.05)$, although $E V L$ was shown to be upregulated to some extent in repeat one of the long-fertile-period group in the microarray experiment; the NPY RNA expression level $(1.00 \pm 0.30$, Fig. 3$)$ of the shortfertile-period group was significantly higher than that of the longfertile-period group $(0.47 \pm 0.06 ; \mathrm{P}<0.05)$; and the RNA levels of TRAK1 in the short-fertile-period and long-fertile-period groups were $1.00 \pm 0.03$ and $2.83 \pm 0.15$, respectively (Fig. 4).

\section{Discussion}

Our results showed that the RNA expressions of the two genes $N P Y$ and $E V L$ were significantly higher in the short-fertile-period 
(a)

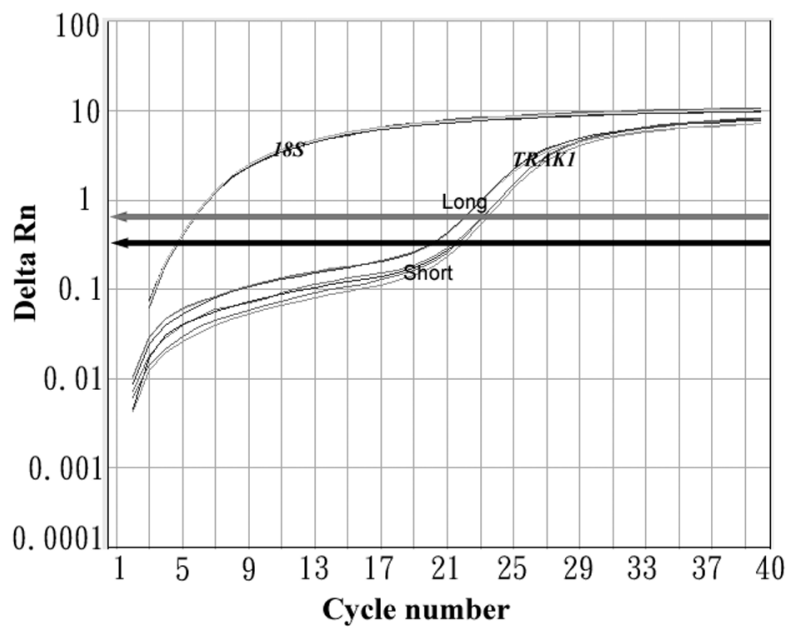

(b)

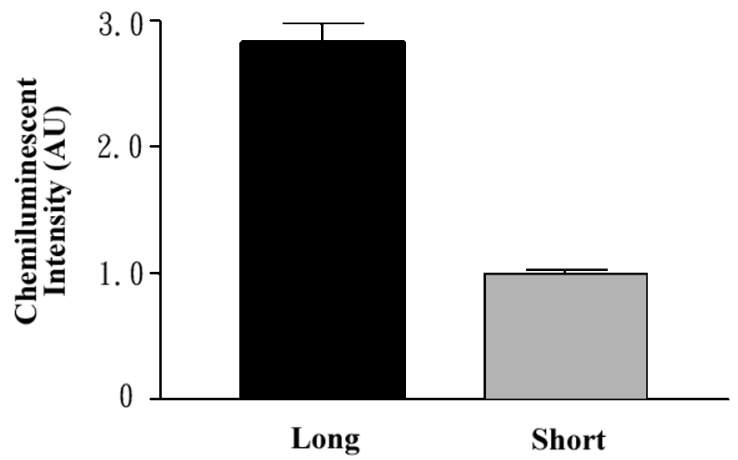

Fig. 4. Differentially expressed $T R A K 1$ gene validation by real-time PCR. (a) Higher amounts of TRAK1 mRNA were expressed in the long-fertile-period group. (b) The quantitative results of TRAK1 expression from (a). Similar results to those observed by microarray demonstrated that the TRAK1 mRNA level was significantly higher in the long-fertile-period group than in the short-fertile-period group. ( $\longleftarrow$ and $\longleftarrow$ indicate the analysis thresholds for TRAK1 and $18 S$, respectively.)

group (Table 1, Figs. 2 and 3) than in the long-fertile-period group; on the other hand, the expression of TRAK1 was significantly increased in the long-fertile-period group as compared with the short-fertile-period group. NPY exists in the central and peripheral nervous system (e.g., in microcirculation in the testis) and induces a decrease in blood flow in the latter $[25,26]$. An increase in NPY expression reduces substance and fluid exchange and decreases the supply of essential elements between blood capillaries and local tissues. In the present study, the sperm reservoir (UV junction) in the short-fertile-period group increasingly expressed NPY; this may repress vascular permeability and decrease the blood supply to the tissues of the UV junction, resulting in a poor microenviron- ment for the supply and production of substances such as glycosaminoglycans (GAGs), hyaluronan in particular, which can prevent the induction of precocious sperm activation [27] to maintain the viability and fertile life of the sperm [28].

EVL has been found to play an important role in the activation of T-cell receptor signaling via regulation of actin dynamics $[29,30]$. The female symptom of semen allergy demonstrates the activated T-cell reaction [31, 32]. Mallmann and Diedrich [33] and Lu et al. [34] demonstrated that the female sperm allergy is an important cause leading to the problem of sperm survival, this allergy was present in the infertile groups. Normal sperm survival and fertility may be maintained by suppression of antisperm immunoreactions through TGF-beta and its receptor (accession no: NM_001031045 and NM_205428) in the UV junction $[35,36]$. All of these immunoreactions may indicate that an allergic response of an EVL-mediated T-cell reaction happened in the birds from the short-fertileperiod group and that sperm cannot survive in the UV junction for a long period of time.

TRAK1 is expressed in many tissues, such as the testis, kidney, smooth muscle and brain; as a trafficking protein, TRAK1 has been suggested to target $O$-Glc-NAc transferase (OGT) to transcriptional complexes for the glycosylation and the suppression of transcription factors [37]. Mitogen-activated protein kinase (MAPK) is required for the activation of spermatozoa [38, 39], which should be repressed when spermatozoa are still in the sperm reservoir [8, 9]. The increase in TRAK1 RNA levels (Table 1 and Fig. 4) in the sperm reservoir of the long-fertile-period group could be facilitative of the inhibition of sperm activation genes, such as MAPK1, through the transcriptional suppression of guanine nucleotide exchange factor (GEF) [40] and the prolongation of the fertile period.

Here, we found that NPY, which reduces substance supply to local tissues, was significantly more greatly expressed at the transcription level in the short-fertile-period group than in the long-fertile-period group. The RNA expression of $E V L$, which is important in the immune response of T-cells, was also significantly increased in the short-fertile-period group. In contrast, TRAK1, the expression of which was significantly increased in the long-fertile-period group as compared with the short-fertile-period group, may be beneficial for the prolongation of sperm life. Although interpretation of the results in the present study is limited and more surveys will be needed to determine the physiological functions of these genes, our results provide evidence that the gene expression of NPY, EVL and TRAK1 changes in association with the length of the fertile period. In conclusion, we performed the first genome-wide expression analysis to compare the differences in gene expression in the sperm reservoir of the female reproductive tract and presented new data to provide an opportunity to increase the understanding of sperm life extension in the female sperm reservoir.

\section{Acknowledgment}

This study was funded by a grant awarded by the National Science Council, Executive Yuan, Taiwan (Grant No. NSC952313-B005-008). 


\section{References}

1. Blesbois E, Brillard JP. Specific features of in vivo and in vitro sperm storage in birds. Animal 2007; 1: 1472-1481. [CrossRef]

2. Birkhead TR. Numbers and size of sperm storage tubules and the duration of sperm storage in birds: a comparative study. Biol J Linn Soc 1992; 45: 363-372. [CrossRef]

3. Scott MA. A glimpse at sperm function in vivo: sperm transport and epithelial interaction in the female reproductive tract. Anim Reprod Sci 2000; 60-61: 337-348. [Medline] [CrossRef]

4. Sarkar S, Sarkar NK, Maiti BR. Oviductal sperm storage structure and their changes during the seasonal (dissociated) reproductive cycle in the soft-shelled turtle Lissemys punctata punctata. J Exp Zool A Comp Exp Biol 2003; 295A: 83-91. [Medline] [CrossRef]

5. Brillard JP, Bakst MR. Quantification of spermatozoa in the sperm-storage tubules of turkey hens and the relation to sperm numbers in the perivitelline layer of eggs. Biol Reprod 1990; 43: 271-275. [Medline] [CrossRef]

6. Wilcox AJ, Weinberg CR, Baird DD. Timing of sexual Intercourse in relation to ovulation - effects on the probability of conception, survival of the pregnancy, and sex of the baby. New Engl J Med 1995; 333: 1517-1521. [Medline] [CrossRef]

7. De Pauw IM, Van Soom A, Laevens H, Verberckmoes S, de Kruif A. Sperm binding to epithelial oviduct explants in bulls with different non-return rates investigated with a new in vitro model. Biol Reprod 2002; 67: 1073-1079. [Medline] [CrossRef]

8. Publicover $\mathrm{S}$, Harper $\mathrm{CV}$, Barratt C. $\left[\mathrm{Ca}^{2+}\right]_{\mathrm{i}}$ signalling in sperm-making the most of what you've got. Nat Cell Biol 2007; 9: 235-242. [Medline] [CrossRef]

9. Suarez SS, Pacey AA. Sperm transport in the female reproductive tract. Hum Reprod Update 2006; 12: 23-37. [Medline] [CrossRef]

10. Smith TT, Yanagimachi R. The viability of hamster spermatozoa stored in the isthmus of the oviduct: the importance of sperm-epithelium contact for sperm survival. Biol Reprod 1990; 42: 450-457. [Medline] [CrossRef]

11. Smith TT. The modulation of sperm function by the oviductal epithelium. Biol Reprod 1998; 58: 1102-1104. [Medline] [CrossRef]

12. Huang MC, Sung YY. Studies on the problems of sperm storage in the oviduct of Tsaiya duck 1 . Repeatability of fertility duration, sperm storage sites and the environment in oviducts. I Agri Assoc China 1988; 144: 58-75. (In Chinese).

13. Dobrinski I, Suarez SS, Ball BA. Intracellular calcium concentration in equine spermatozoa attached to oviductal epithelial cells in vitro. Biol Reprod 1996; 54: 783-788. [Medline] [CrossRef]

14. Mero KN, Ogasawara F. Dimensions of uterovaginal sperm-storage tubules of the chicken and their possible significance in sperm release. Poult Sci 1970; 49: 1304-1308. [Medline]

15. Bakst MR. Fate of fluorescent stained sperm following insemination: new light on oviducal sperm transport and storage in the turkey. Biol Reprod 1994; 50: 987-992. [Medline] [CrossRef]

16. Lefebvre R, Chenoweth PJ, Drost M, LeClear CT, MacCubbin M, Dutton JT, Suarez SS. Characterization of the oviductal sperm reservoir in cattle. Biol Reprod 1995; 53: 1066-1074. [Medline] [CrossRef]

17. Wagner A, Ekhlasi-Hundrieser M, Hettel C, Petrunkina A, Waberski D, Nimtz M, Topfer-Petersen E. Carbohydrate-based interactions of oviductal sperm reservoir formation-studies in the pig. Mol Reprod Dev 2002; 61: 249-257. [Medline] [CrossRef]

18. Rodriguezmartinez $\mathbf{H}$, Saravia $F$, Wallgren $\mathbf{M}$, Tienthai $\mathbf{P}$, Johannisson $A$, Vázquez JM, Martínez E, Roca J, Sanz L, Calvete JJ. Boar spermatozoa in the oviduct. Theriogenology 2005; 63: 514-535. [Medline] [CrossRef]

19. Lefebvre R, Lo M, Suarez S. Bovine sperm binding to oviductal epithelium involves fucose recognition. Biol Reprod 1997; 56: 1198-1204. [Medline] [CrossRef]

20. Skinner BM, Robertson LBW, Tempest HG, Langley EJ, Ioannou D, Fowler KE, Crooijmans RPMA, Hall AD, Griffin DK, Voelker M. Comparative genomics in chicken and Pekin duck using FISH mapping and microarray analysis. BMC Genomics 2009; 10: 357-367. [Medline] [CrossRef]

21. Cheng YS, Rouvier R, Poivey JP, Tai JJL, Tai C, Huang SC. Selection responses for the number of fertile eggs of the Brown Tsaiya duck (Anas platyrhynchos) after a single artificial insemination with pooled Muscovy (Cairina moschata) semen. Genet Sel Evol 2002; 34: 597-611. [Medline] [CrossRef]

22. Poivey JP, Cheng YS, Rouvier R, Tai C, Wang CT, Liu HL. Genetic parameters of reproductive traits in Brown Tsaiya ducks artificially inseminated with semen from Muscovy drakes. Poult Sci 2001; 80: 703-709. [Medline]

23. Li C, Wong WH. Model-based analysis of oligonucleotide arrays: model validation, design issues and standard error application. Genome Bio 2001; 2: research0032.1-research.11.

24. Dahlquist KD, Salomonis N, Vranizan K, Lawlor S, Conklin B. GenMAPP, a new tool for viewing and analyzing microarray data on biological pathways. Nat Genet 2002; 31: 19-20. [Medline] [CrossRef]

25. Kopp J, Collin O, Villar M, Mullins D, Bergh A, Hokfelt T. Regulation of neuropeptide $\mathrm{Y}$ Y1 receptors by testosterone in vascular smooth muscle cells in rat testis. Neuroendocrinology 2008; 88: 216-226. [Medline] [CrossRef]

26. Collin O, Enfält E, Aström M, Lissbrant E, Bergh A. Unilateral injection of neuropeptide $\mathrm{Y}$ decreases blood flow in the injected testis but may also increase blood flow in the contralateral testis. J Androl 1998; 19: 580-584. [Medline]

27. Lemoine M, Mignon-Grasteaue S, Grasseau I, Magistrinia M, Blesbois E. Ability of chicken spermatozoa to undergo acrosome reaction after liquid storage or cryopreservation. Theriogenology 2011; 75: 122-130. [Medline] [CrossRef]

28. Tienthai P, Suzuki K, Pertoft H, Kjellen L, Rodriguez-Martinez H. Production of glycosaminoglycans by the porcine oviduct in relation to sperm storage. Reprod Dom Anim 2000; 35: 167-170

29. Krause M, Sechi AS, Konradt M, Monner D, Gertler FB, Wehland J. Fyn-binding protein (Fyb)/SLP-76-associated protein (SLAP), Ena/Vasodilator-stimulated phosphoprotein (VASP) proteins and the Arp2/3 complex link T Cell receptor (TCR) signaling to the actin cytoskeleton. J Cell Biol 2000; 149: 181-194. [Medline] [CrossRef]

30. Lambrechts A, Kwiatkowski AV, Lanier LM, Bear JE, Vandekerckhove J, Ampe C, Gertler FB. cAMP-dependent protein kinase phosphorylation of EVL, a Mena/VASP relative, regulates its interaction with actin and SH3 domains. J Biol Chem 2000; 275 : 36143-36151. [Medline] [CrossRef]

31. Sonnex C. Genital allergy. Sex Transm Infect 2004; 80: 4-7. [Medline]

32. Kint B, Degreef H, Dooms-Goossens A. Combined allergy to human seminal plasma and latex: case report and review of the literature. Contact Dermatitis 1994; 30 7-11. [Medline] [CrossRef]

33. Mallmann P, Diedrich K. Cell mediated immunity in infertility. Arch Gynecol Obstet 1992; 251: 55-63. [Medline] [CrossRef]

34. Lu JC, Huang YF, Lu NQ. Antisperm immunity and infertility. Expert Rev Clin Immunol 2008; 4: 113-126. [Medline] [CrossRef]

35. Das SC, Isobe N, Yoshimura Y. Analysis of changes in the expression of transforming growth factor- $\beta \mathrm{s}$ in the uterovaginal junction of hen oviduct in response to sperm concerning their significance in sperm survivability. J Poul Sci 2010; 47: 326-332. [CrossRef]

36. Das SC, Isobe N, Nishibori M, Yoshimura Y. Expression of TGF- $\beta$ isoforms and their receptors in uterovaginal junction of hen oviduct in presence or absence of resident sperm with reference to sperm storage. Reproduction 2006; 132: 781-790. [Medline] [CrossRef]

37. Iyer SPN, Akimoto Y, Hart GW. Identification and cloning of a novel family of coiled-coil domain proteins that interact with O-GlcNAc transferase. J Biol Chem 2003; 278: 5399-5409. [Medline] [CrossRef]

38. Almog T, Naor Z. Mitogen activated protein kinases (MAPKs) as regulators of spermatogenesis and spermatozoa functions. Mol Cell Endocrinol 2008; 282: 39-44. [Medline] [CrossRef]

39. Lemoine M, Dupont J, Guillory V, Tesseraud S, Blesbois E. Potential involvemen of several signaling pathways in initiation of the chicken acrosome reaction. Biol Reprod 2009; 81: 657-665. [Medline] [CrossRef]

40. Murphy LO, Blenis J. MAPK signal specificity: the right place at the right time. Trends Biochem Sci 2006; 31: 268-275. [Medline] [CrossRef] 